\title{
Strategi Customer Relationship Management (CRM) PT Angkasa Pura II (Persero)
}

\author{
Janiar Puspa Wildyaksanjani ${ }^{1}$ dan Dadang Sugiana ${ }^{2}$ \\ ${ }^{1}$ Institut Teknologi Nasional Bandung \\ ${ }^{2}$ Universitas Padjadjaran
}

\begin{abstract}
ABSTRAK
Penelitian ini bertujuan untuk mengetahui alasan PT Angkasa Pura II (Persero) melakukan strategi Customer Relationship Management (CRM), mengetahui strategi Customer Relationship Management (CRM) yang dilakukan PT Angkasa Pura II (Persero) dan untuk mengetahui persepsi mitra usaha pada strategi Customer Relationship Management (CRM) yang dilakukan PT Angkasa Pura II (Persero) di Bandara Internasional Husein Sastranegara Bandung. Metode yang digunakan dalam penelitian ini adalah metode kualitatif dengan pendekatan studi kasus. Teknik analisis data yang digunakan adalah teknik analisis data interaktif Miles dan Huberman yang terdiri dari reduksi data, penyajian data, dan diakhiri dengan penarikan kesimpulan/verifikasi. Teknik pengumpulan data dilakukan dengan wawancara mendalam, observasi, dan studi dokumentasi. Hasil penelitian menunjukkan bahwa yang menjadi alasan PT Angkasa Pura II (Persero) melakukan strategi Customer Relationship Management (CRM) di Bandara Internasional Husein Sastranegara Bandung adalah untuk lebih meningkatkan pelayanan kepada mitra usaha sehingga tercipta hubungan jangka panjang yang lebih baik serta mendorong loyalitas dari mitra usaha kepada PT Angkasa Pura II (Persero). Strategi Customer Relationship Management (CRM) yang dilakukan PT Angkasa Pura II (Persero) di Bandara Internasional Husein Sastranegara Bandung adalah dengan memberikan pelayanan prima kepada mitra usaha dan yang membedakan Bandara Internasional Husein Sastranegara Bandung dengan bandara lain di Indonesia adalah adanya program inovasi seperti lucky draw dan piagam penghargaan. Persepsi mitra usaha pada strategi Customer Relationship Management (CRM) yang dilakukan PT Angkasa Pura II (Persero) di Bandara Internasional Husein Sastranegara Bandung cukup beragam mulai dari persepsi yang bersifat positif ataupun negatif. Namun secara garis besar persepsi pelanggan lebih kepada masukan atau kritikan agar PT Angkasa Pura II (Persero) meningkatkan kualitas pelayanannya di Bandara Internasional Husein Sastranegara Bandung.
\end{abstract}

Kata-kata Kunci: Bandara; bandung; customer relationship management (crm); inovasi; strategi

\section{PT Angkasa Pura II (Persero) Customer Relationship Management (CRM) Strategy}

\begin{abstract}
This research aims to discover why PT Angkasa Pura II (Persero) pursuing a strategy of Customer Relationship Management (CRM), to see what kind of strategies used by the Customer Relationship Management (CRM) conducted by PT Angkasa Pura II (Persero) and to know the perception of business partners on a strategy of Customer Relationship Management (CRM) conducted by PT Angkasa Pura II (Persero) at Bandung Husein Sastranegara International Airport. The method used in this research is qualitative method with case study approach. Data analysis technique used is the technique of interactive data analysis by Miles and Huberman consisting of data reduction, data presentation, and ends with a conclusion / Verification. Data collected by interview, observation and documentation. The results showed that the reason PT Angkasa Pura II (Persero) pursuing a strategy of Customer Relationship Management (CRM) at International Airport Husein Sastranegara is to further improve service to its business partners so as to create a better long-term relationships and to encourage the loyalty of PT Angkasa Pura II (Persero) business partners. Strategic Customer Relationship Management (CRM) conducted by PT Angkasa Pura II (Persero) at International Airport Husein Sastranegara is to provide excellent service to business partners and the distinction between Bandung International Airport Husein Sastranegara to other airports in Indonesia is their innovation programs such as lucky draws and a plaque of appreciation. The Perception of business partners on a strategy of Customer Relationship Management (CRM) conducted by PT Angkasa Pura II (Persero) at Bandung Husein Sastranegara International Airport is quite diverse. There are positive and negative perception. However, generally speaking, the customer perceptionare more about feedback or criticism toward PT Angkasa Pura II (Persero) to improve the quality of its services in Bandung Husein Sastranegara International Airport.
\end{abstract}

Keywords: Airport; bandung; customer relationship management (crm); innovation; strategy

Korespondensi: Janiar Puspa Wildyaksanjani, S.Ds., M.I.Kom. Institut Teknologi Nasional Bandung Jl.PH. Hasan Mustapa No.23, Jawa Barat.Email: janiwildyaksanjani@gmail.com 


\section{PENDAHULUAN}

Customer Relationship Management (CRM) saat ini merupakan salah satu strategi yang digunakan oleh perusahaan untuk lebih mengetahui dan memahami pelanggannya, sehingga perusahaan dapat memberikan pelayanan yang terbaik serta membina hubungan jangka panjang yang lebih baik dengan pelanggannya, Turban, dkk (2002: 136) berpendapat bahwa Customer Relationship Management (CRM) adalah suatu pendekatan yang memandang bahwa pelanggan adalah inti dari bisnisnya dan keberhasilan suatu perusahaan tergantung dari bagaimana mereka mengelola hubungannya secara efektif. Customer Relationship Management (CMR), yang bertujuan untuk meningkatkan pertumbuhan profitabilitas perusahaan jangka panjang (Semuel, 2012). Hubungan dengan pelanggan (customer relations), di mana hal ini mencakup kegiatan-kegiatan seperti memberi informasi kepada pelanggan atau nasabah, menjelaskan prosedur, tata cara, waktu penyelenggaraan acara (Datuela, 2013).

Suatu organisasi yang customer-centric terus-menerus berusaha melayani setiap pelanggan dengan empati dengan selalu memberdayakan pelanggan, bukan menjadikan pelanggan sebagai sasaran. Fokus proses pemasaran yang tadinya dipusatkan pada pertukaran diperluas ke arah relationship yang memiliki cakrawala waktu yang panjang. Di dalam setiap kegiatan pertukaran terdapat setiap hubungan relasional (relationship) yang akan menjadi hubungan interaktif dan terusmenerus jika tercipta kepuasan, kepercayaan dan komitmen (Utami, 2006).

Pengertian CRM adalah manajemen hubungan pelanggan yaitu suatu jenis manajemen yang secara khusus membahas teori mengenai penanganan hubungan antara perusahaan dengan pelanggannya dengan tujuan meningkatkan nilai perusahaan di mata pelanggannya. CRM melingkupi semua aspek yang berhubungan dengan calon pelanggan dan pelanggan saat ini. Lebih lanjut Customer Relationship Management adalah strategi tingkat korporasi yang berfokus pada pembangunan dan pemeliharaan hubungan dengan pelanggan, jadi CRM lebih menekankan pada pendekatan holistik terhadap falsafah organisasi yang menekankan hubungan yang erat dengan pelanggan (Ishak, 2006).

Pelayanan merupakan faktor yang sangat penting bagi perusahaan, terutama bagi perusahaan yang bergerak dalam bidang jasa. PT Angkasa Pura II (Persero) adalah salah satu dari perusahaan BUMN dalam Kementerian Perhubungan yang terlibat dalam jasa bandar udara dan segala macam pelayanan yang berhubungan dengan bandar udara di Indonesia bagian barat. Jasa yang diberikan bandar udara adalah loading services, hangar services, airplane passenger services, flight services, aviobridge service dan counter services. Sebagai Badan Usaha Milik Negara, PT Angkasa Pura II (Persero) selalu melaksanakan kewajiban untuk membayar deviden kepada negara selaku pemegang saham. PT Angkasa Pura II (Persero) juga senantiasa berkomitmen untuk memberikan pelayanan yang terbaik dan perlindungan konsumen kepada pengguna jasa bandara, menerapkan praktik tata kelola perusahaan yang baik, meningkatkan kesejahteraan karyawan dan keluarganya serta meningkatkan kepedulian sosial terhadap masyarakat umum dan lingkungan sekitar bandara melalui program Customer Relationship Management (CRM) (Arsip PT Angkasa Pura II).

Salah satu bandar udara di bawah pengelolaan PT Angkasa Pura II (Persero) yang saat ini mengalami peningkatan cukup signifikan baik sisi pihak yang menyewa sarana dan prasarana jasa transportasi udara ataupun jumlah penumpang adalah Bandara Internasional Husein Sastranegara Bandung. Terlihat pada arsip buku rencana jangka panjang PT Angkasa Pura II (Persero), ditemukan data lompatan penting yang diraih Bandara Internasional Husein Sastranegara Bandung. Setelah bertahun-tahun merugi, sejak 2009 Bandara Internasional Husein Sastranegara Bandung meraih keuntungan sebesar Rp. 6,41 miliar. Keuntungan ini terus meningkat pada tahun-tahun berikutnya. Berdasarkan pada prestasi tersebut membuat PT Angkasa Pura II (Persero) sejak tahun 2011 memasukkan Bandara Internasional Husein Sastranegara Bandung dalam kategori developing dengan skor 1,75 (Kasali, 2014: 81).

Ada beberapa faktoryang menjadi penyebab Bandara Internasional Husein Sastranegara Bandung mampu melakukan lompatan penting tersebut. Pertama, peran kota Bandung itu sendiri, dimana saat ini di kota Bandung banyak 
tumbuh industri-industri kreatif, terutama yang berbasis fashion dan wisata kuliner. Banyak orang datang ke kota Bandung hanya untuk berburu produk-produk fashion atau sekedar untuk berwisata kuliner. Kedua, bertambahnya maskapai-maskapai penerbangan yang melayani penerbangan dengan rute ke kota Bandung baik nasional ataupun internasional sehingga cukup berdampak pada bertambahnya jumlah wisatawan domestik atau internasional ke kota Bandung.

Untuk mengetahui data perbandingan peningkatan penumpang domestik dan internasional Januari 2012 - Mei 2013 dapat dilihat pada Gambar 1. Grafik pada gambar 1 menunjukkan bahwa setiap tahunnya terjadi peningkatan yang cukup signifikan pada jumlah penumpang, baik penumpang yang datang maupun yang berangkat dari Bandara Internasional Husein Sastranegara Bandung.

Namun seiring dengan perkembangan tersebut, saat ini PT Angkasa Pura II (Persero) Bandara Internasional Husein Sastranegara Bandung harus menghadapi berbagai macam masalah, terutama masalah keluhan yang datang dari masyarakat pengguna jasa transportasi udara terhadap pelayanan yang diberikan termasuk didalamnya penyediaan sarana dan prasarana yang berhubungan dengan bandar udara yang secara otomatis permasalahan tersebut akan sangat berdampak pada mitra usaha PT Angkasa Pura II (Persero) Bandara Internasional Husein Sastranegara Bandung salah satunya maskapai penerbangan.

Peningkatan jumlah penumpang membuat Bandara Internasional Husein Sastranegara Bandung mengalami kelebihan kapasitas sehingga mengharuskan Bandara Internasional Husein Sastranegara Bandung memperluas kapasitas terminalnya. Salah satu media daring di Indonesia, yaitu detik.com bahkan menuliskan artikel berjudul "CIDEV: 3 Kondisi Bandara Internasional di Indonesia Mencemaskan". Muhammad Rifai Darus selaku ketua dari The Center for Indonesia Development Review (CIDEV) menjelaskan bahwa tiga Bandara Internasional di Indonesia yaitu Bandara Soekarno-Hatta, Bandara Juanda, dan Bandara Husein Sastranegara mengalami peningkatan penumpang yang cukup luar biasa. "Peningkatannya mencapai $20-45 \%$ di tiga bandara tersebut. Namun sayang, kapasitas dan fasilitas di ketiga Bandara Internasional di Indonesia itu dalam kondisi yang mencemaskan". Berdasarkan pengamatan lembaga ini, peningkatan jumlah penumpang

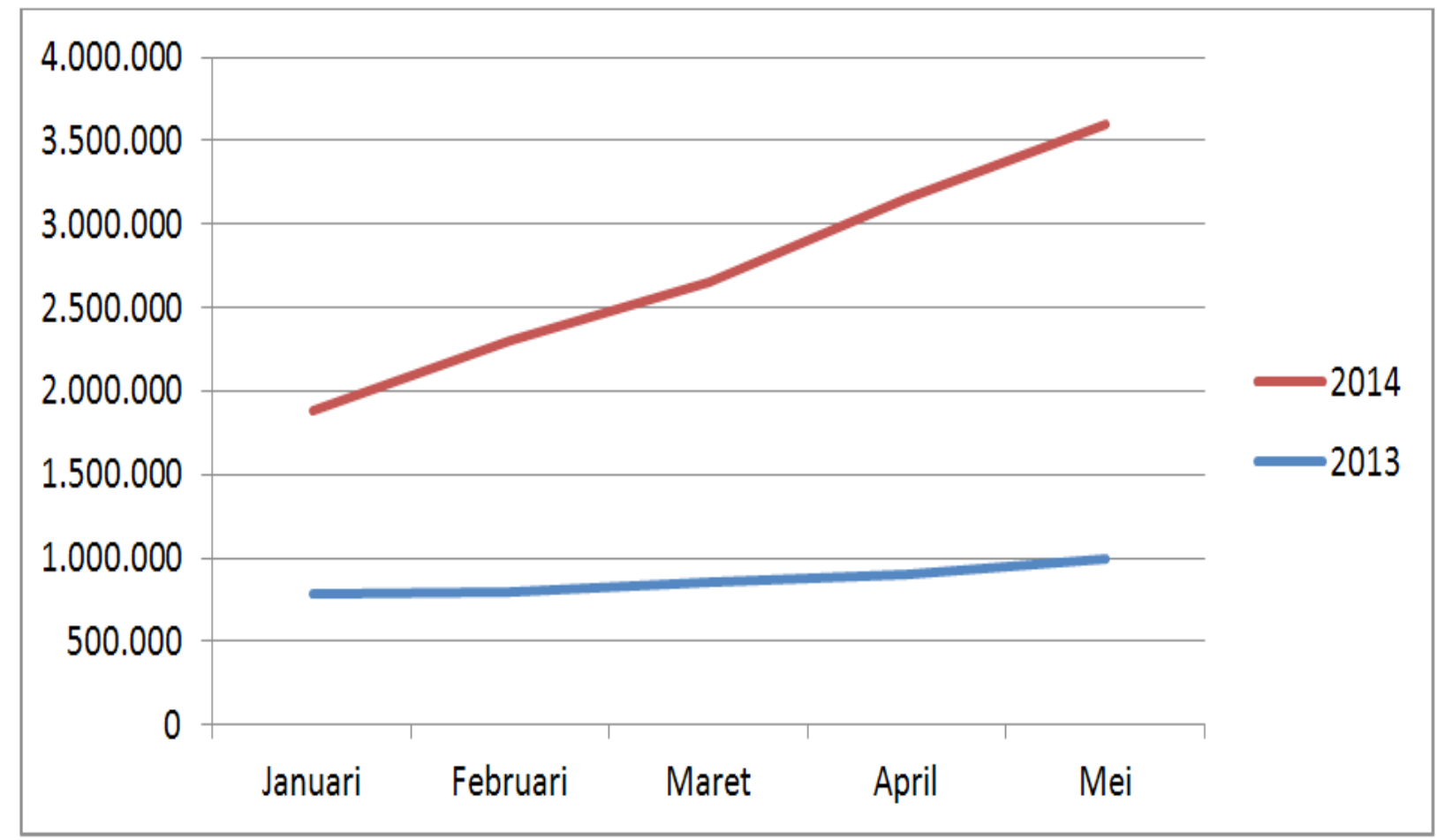

Sumber: Arsip PT Angkasa Pura II, 2013, 2014

Gambar 1 Data Perbandingan Peningkatan Penumpang Domestik dan Internasional Januari 2013 - Mei 2014 PT Angkasa Pura II (Persero) Bandung 
di ketiga bandara ternyata tidak diimbangi dengan penambahan kapasitas dan fasilitas yang memadai. Bandara Husein Sastranegara Bandung merupakan bandara yang potensial, dengan pertumbuhan penumpang mencapai $25 \%$ pertahun. Pada 2014, diperkirakan pergerakan penumpang internasional dan domestik di Bandara Husein Sastranegara Bandung mencapai 2,6 juta penumpang atau sekitar 300\% melebihi kapasitas yang ada. Kenaikan ini karena tingginya penerbangan menuju kota Bandung dan dibukanya beberapa rute dan jadwal penerbangan baru dari dan ke kota Bandung (ken/ndr, 2011).

PT Angkasa Pura II (Persero) sebagai pengelola Bandara Internasional Husein Sastranegara Bandung sudah sewajibnya memikirkan kepuasan dari pengguna jasanya. Langkah yang ditempuh PT Angkasa Pura II (Persero) untuk mengetahui apa yang menjadi keluhan pelanggan guna meningkatkan pelayanan di Bandara Internasional Husein Sastranegara Bandung adalah dengan menggunakan SLA (Service Level Agreement) dan SLG (Service Level Guarantee) dengan survei Customer Satisfaction Index (CSI) yang dilakukan satu tahun sekali oleh penilai-penilai independen. Pengukuran CSI ini meliputi 4 item, yakni tingkat kepuasan penumpang, maskapai penerbangan, konsesioner (tenant), dan kargo. Semua item itu adalah penyumbang pendapatan bagi PT Angkasa Pura II (Persero). Adapun hasil survei yang telah dilakukan di Bandara Husein Sastranegara pada tahun 2015 ditunjukkan oleh Tabel 1.

Berdasarkan data pada tabel 1 dapat dilihat bahwa pada tahun 2015, mayoritas responden merasa tidak puas dengan layanan dan fasilitas yang disediakan PT. Angkasa Pura II (Persero) di Bandara Internasional Husein Sastranegara Bandung. Melihat hasil survei tersebut PT. Angkasa Pura II (Persero) wajib segera melakukan perbaikan-perbaikan dalam hal layanan dan fasilitas apabila tidak ingin ditinggalkan oleh konsumennya.

Untuk mengantisipasi kelebihan kapasitas

Tabel 1 Data Statistik Keluhan Pelanggan Bandara Internasional Husein Sastranegara Bandung

\begin{tabular}{|c|c|c|c|c|c|c|}
\hline \multirow{2}{*}{$\begin{array}{l}\text { Butir } \\
\text { Layanan } \\
\& \text { Fasilitas }\end{array}$} & 5 & 4 & 3 & 2 & 1 & \multirow[b]{2}{*}{$\begin{array}{l}\text { Kriteria } \\
\text { Akhir }\end{array}$} \\
\hline & $\begin{array}{l}\text { Sangat } \\
\text { Puas }\end{array}$ & Puas & Cukup & $\begin{array}{l}\text { Tidak } \\
\text { Puas }\end{array}$ & $\begin{array}{c}\text { Sangat } \\
\text { Tidak Puas }\end{array}$ & \\
\hline Akses & $2 \%$ & $14 \%$ & $20 \%$ & $32 \%$ & $43 \%$ & $\begin{array}{c}\text { Sangat Tidak } \\
\text { Puas }\end{array}$ \\
\hline Rambu-rambu \& Informasi & $11 \%$ & $17 \%$ & $20 \%$ & $31 \%$ & $21 \%$ & Tidak Puas \\
\hline Pelayanan Check-In & $19 \%$ & $33 \%$ & $23 \%$ & $16 \%$ & $6 \%$ & Puas \\
\hline Imigrasi \& Bea Cukai & $11 \%$ & $23 \%$ & $32 \%$ & $18 \%$ & $16 \%$ & Cukup \\
\hline Pemeriksaan Keamanan & $30 \%$ & $31 \%$ & $23 \%$ & $15 \%$ & $11 \%$ & Puas \\
\hline $\begin{array}{l}\text { Fasilitas Berbelanja \& } \\
\text { Restoran }\end{array}$ & $12 \%$ & $21 \%$ & $37 \%$ & $17 \%$ & $13 \%$ & Cukup \\
\hline $\begin{array}{l}\text { Kenyamanan \& Fasilitas } \\
\text { Terminal }\end{array}$ & $4 \%$ & $12 \%$ & $17 \%$ & $39 \%$ & $28 \%$ & Tidak puas \\
\hline Lingkungan Bandara & $13 \%$ & $17 \%$ & $18 \%$ & $28 \%$ & $24 \%$ & Tidak Puas \\
\hline Pelayanan Kedatangan & $6 \%$ & $13 \%$ & $18 \%$ & $37 \%$ & $26 \%$ & Tidak Puas \\
\hline & Rata & Skor & & & & 2,57 \\
\hline
\end{tabular}


yang terjadi, PT Angkasa Pura II (Persero) memiliki rencana untuk melakukan perluasan terminal bandara di Bandara Internasional Husein Sastranegara Bandung. Selain itu untuk dapat menjaga loyalitas pelanggan yang sudah ada, PT Angkasa Pura II (Persero) selaku pengelola Bandara Internasional Husein Sastranegara Bandung harus dapat membina hubungan baik dengan pelanggannya terutama dengan mitra usaha PT Angkasa Pura II (Persero) serta masyarakat pengguna Bandara Internasional Husein Sastranegara Bandung. Strategi yang digunakan oleh PT Angkasa Pura II (Persero) untuk menjalin hubungan yang baik dengan pelanggannya adalah melalui aktivitas Customer Relationship Management (CRM). Adapun divisi yang memiliki peran untuk melaksanakan tugas aktivitas customer relations di PT Angkasa Pura II (Persero) adalah Dinas Administrasi komersial dimana salah satu tugas dan tanggung jawabnya adalah menyiapkan dan melaksanakan kegiatan kehumasan, termasuk didalamnya adalah melaksanakan aktivitas Customer Relationship Management (CRM) secara internal ataupun eksternal. Menurut Mukhroman (2013: 206) humas adalah kegiatan komunikasi yang terencana, terorganisir dan berkelanjutan antara organisasi dan publik sasaran, yang memiliki esensi fungsi humas untuk mengantisipasi sikap publik, melaksanakan fungsi radar dan kontrol sosial secara berkelanjutan, dan melaksanakan kegiatan terencana untuk mendapatkan pengertian dan pemahaman publik terhadap suatu peristiwa atau kebijakan organisasi yang memiliki dampak terhadap organisasi.

Customer relations merupakan strategi baru untuk mengikat konsumen kepada suatu perusahaan. Tujuan customer relations tersebut adalah untuk menciptakan pelanggan yang loyal dan berkomitmen terhadap produk atau jasa yang dihasilkan oleh suatu perusahaan. Dalam sebuah perusahaan, melalui aktivitas customer relations akan berupaya semaksimal mungkin untuk mempertahankan loyalitas pelanggannya.

Menurut Ruslan (2008: 294), tujuan dari customer relations adalah mempertahankan pelanggan, menarik pelanggan baru, pemasaran produk atau layanan baru, kecepatan dalam penanganan keluhan, dan mengurangi biaya. Selain tujuan tersebut, dengan melakukan aktivitas Customer Relationship Management (CRM) PT Angkasa Pura II (Persero) berharap kepuasan pelanggan dapat lebih meningkat sehingga pelanggan tidak menggunakan jasa yang disediakan PT Angkasa Pura II (Persero)

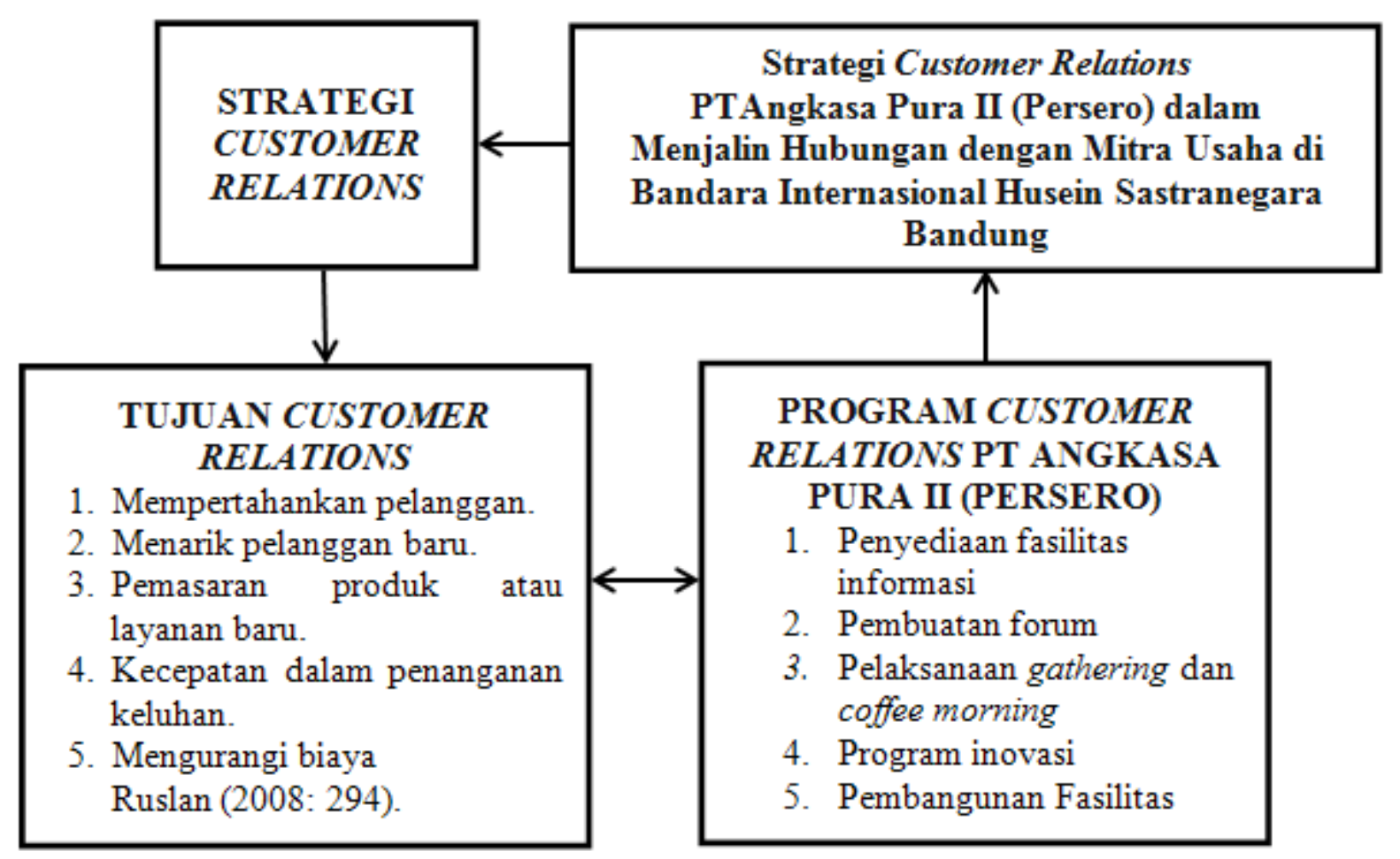

Sumber: Penelitian, 2016

Gambar 2 Kerangka Penelitian 
karena terpaksa atau atas dasar karena tidak ada bandara lain di kota Bandung karena hal tersebut akan berdampak buruk pada perkembangan bisnis yang dilakukan PT Angkasa Pura II (Persero) khusunya PT Angkasa Pura II (Persero) cabang Bandung.

Melihat permasalahan yang harus dihadapi oleh PT Angkasa Pura II (Persero) serta cara yang ditempuh PT Angkasa Pura II (Persero) untuk mengantisipasinya melalui strategi Customer Relationship Management (CRM), maka penulis tertarik untuk melakukan penelitian dengan judul: "Strategi Customer Relationship Management (CRM) PT Angkasa Pura II (Persero)": Studi Kasus tentang Strategi Customer Relationship Management (CRM) PT Angkasa Pura II (Persero) dalam Menjalin Hubungan dengan Mitra Usaha di Bandara Internasional Husein Sastranegara Bandung.

Berdasarkan landasan teori di atas, maka peneliti membuat kerangka pemikiran untuk menggambarkan strategi customer relations PT Angkasa Pura II (Persero) dalam menjalin hubungan dengan mitra usaha di Bandara Internasional Husein Sastranegara Bandung.

\section{METODE PENELITIAN}

Pendekatan dalam penelitian ini adalah studi kasus. Studi kasus merupakan strategi penelitian di mana di dalamnya peneliti menyelidiki secara cermat suatu program, peristiwa, aktivitas, proses, atau sekelompok individu. Kasus-kasus dibatasi oleh waktu dan aktivitas, dan peneliti mengumpulkan informasi secara lengkap dengan menggunakan berbagai prosedur pengumpulan data berdasarkan waktu yang telah ditentukan (Stake dalam Creswell, 2012: 20).

Fokus studi kasus adalah spesifikasi kasus dalam suatu kejadian baik itu yang mencakup individu, kelompok budaya ataupun suatu potret kehidupan. Beberapa karakteristik dari suatu studi kasus yaitu: (1) Mengidentifikasi "kasus" untuk suatu studi; (2) Kasus tersebut merupakan sebuah "sistem yang terikat" oleh waktu dan tempat; (3) Studi kasus menggunakan berbagai sumber informasi dalam pengumpulan datanya untuk memberikan gambaran secara terinci dan mendalam tentang respons dari suatu peristiwa dan (4) Menggunakan pendekatan studi kasus, peneliti akan "menghabiskan waktu" dalam menggambarkan konteks atau setting untuk suatu kasus (Creswell, 2012: 36-38).

Tujuan penggunaan penelitian studi kasus menurut Yin (2011:2) adalah untuk menjelaskan bagaimana keberadaan dan mengapa kasus tersebut terjadi. Penelitian studi kasus bukan sekedar menjawab pertanyaan penelitian tentang 'apa' (what) objek yang diteliti, tetapi lebih menyeluruh dan komprehensif lagi adalah tentang 'bagaimana' (how) dan 'mengapa' (why).

Berdasarkan paparan di atas, dapat diungkapkan bahwa studi kasus adalah sebuah eksplorasi dari "suatu sistem yang terikat" atau "suatu kasus/beragam kasus" yang dari waktu ke waktu melalui pengumpulan data yang mendalam serta melibatkan berbagai sumber informasi yang "kaya" dalam suatu konteks. Sistem terikat ini diikat oleh waktu dan tempat sedangkan kasus dapat dikaji dari suatu program, peristiwa, aktivitas atau suatu individu (Creswell, 2012: 61). Dengan perkataan lain, studi kasus merupakan penelitian dimana peneliti menggali suatu fenomena tertentu (kasus) dalam suatu waktu dan kegiatan (program, event, proses, institusi atau kelompok sosial) serta mengumpulkan informasi secara terinci dan mendalam dengan menggunakan berbagai prosedur pengumpulan data selama periode tertentu.

Dengan menggunakan pendekatan studi kasus, penulis berusaha mengungkapkan secara cermat, terperinci dan mendalam berdasarkan pada berbagai sumber informasi mengenai strategi Customer Relationship Management (CRM) PT Angkasa Pura II (Persero) dalam menjalin hubungan dengan mitra usaha di Bandara Internasional Husein Sastranegara Bandung.

Dalam menentukan informan guna memperoleh informasi, penulis menggunakan teknik purposive, dimana peneliti mengambil informan berdasarkan kriteria-kriteria tertentu yang penulis buat berdasarkan tujuan riset (Kriyantono, 2008: 156). Pertimbangan tertentu ini, misalnya orang tersebut yang dianggap paling tahu tentang apa yang kita harapkan, atau mungkin dia sebagai penguasa sehingga akan memudahkan peneliti menjelajahi objek/situasi sosial yang akan diteliti (Sugiyono, 2012: 54). Pada penelitian ini, peneliti menggunakan teknik purposive sampling dengan menentukan key informan yang akan menjadi narasumber yaitu 10 orang yang berhubungan dengan 
strategi Customer Relationship Management (CRM) PT. Angkasa Pura II (Persero).

Berikut kriteria key informant yang telah ditentukan dalam penelitian ini: (1) Pihak PT Angkasa Pura II (Persero) cabang Bandung yang bertanggung jawab dalam melaksanakan strategi customer relations yaitu General Manager dan Staf Dinas Administrasi dan Komersial PT Angkasa Pura II (Persero) cabang Bandung, (2) Mitra usaha PT Angkasa Pura II (Persero) yaitu maskapai penerbangandan konsesioner yang sudah menjadi mitra usaha lebih dari 3-10 tahun, (3) Penumpang yang memiliki frekuensi menggunakan pesawat terbang 1-2 kali dalam satu bulan di Bandara Internasional Husein Sastranegara Bandung, dan (4) Mitra kerja PT Angkasa Pura II (Persero) cabang Bandung, TNI Angkatan Udara sebagai pemilik lahan Bandara Internasional Husein Sastranegara Bandung serta wartawan.

Teknik pengumpulan data adalah teknik yang digunakan dalam proses pengadaan data untuk kepentingan penelitian. Pengumpulan data adalah prosedur yang sistematis dan standar untuk memperoleh data yang diperlukan (Moleong, 2007: 134). Teknik pengumpulan data yang diperlukan dalam penelitian ini adalah obeservasi, wawancara mendalam dan dokumentasi. Pada penelitian ini, penulis menggunakan teknik analisis data interaktif Miles dan Huberman. Pada model interaktif, reduksi data dan penyajian data memperhatikan hasil data yang dikumpulkan, kemudian proses penarikan kesimpulan dan verifikasi.

Setiap penelitian memerlukan uji keabsahan data atau uji validitas, dan pemeriksaan terhadap keabsahan data mutlak dilakukan, sehingga penelitian tersebut benarbenar dapat dipertanggungjawabkan dari segala segi (Moleong, 2007: 320). Pengujian data ini diperlukan untuk membuktikan apakah data yang diperoleh sudah benar atau belum. Pengujian keabsahan data dalam penelitian ini dilakukan dengan perpanjangan keikutsertaan yaitu dengan ikut serta dalam memperoleh data dari informan maupun data dari PT Angkasa Pura II. Selain menggunakan teknik perpanjangan keikutsertaan, peneliti juga menggunakan teknik triangulasi kejujuran, sumber, metode dan teori.

Triangulasi kejujuran peneliti yaitu cara menguji kejujuran, subjektivitas, dan kemampuan peneliti dengan meminta bantuan dari peneliti lain untuk melakukan pengecekan langsung, wawancara ulang, serta merekam data yang sama di lapangan. Triangulasi dengan sumber berarti membandingkan dan mengecek balik (cross check) derajat kepercayaan suatu informasi yang memperoleh waktu dan alat yang berbeda dalam penelitian kualitatif dengan jalan sebagai berikut: (1) Membandingkan data hasil pengamatan dengan hasil wawancara, (2) Membandingkan apa yang dikatakan orang di depan umum dengan apa yang dikatakan orang secara pribadi, (3) Membandingkan apa yang dikatakan orang-orang tentang situasi penelitian dengan apa yang dikatakan sepanjang waktu, (4) Membandingkan keadaan dan perspektif seseorang dengan berbagai pendapat dan pendangan orang lain, seperti rakyat biasa, orang yang berpendidikan menengah, atau tinggi, (5) Membandingkan hasil wawancara dengan isu suatu dokumen yang berkaitan (Moleong, 2005: 335).

Triangulasi dengan metode triangulasi ini dilakukan dengan melakukan pengecekan terhadap penggunaan metode pengumpulan data, apakah informasi yang didapat dari hasil wawancara sama dengan metode observasi yang dilakukan, atau apakah hasil observasi sesuai dengan informasi yang diberikan ketika interview. Apabila terjadi perbedaan, maka penulis harus dapat menjelaskan perbedaan itu, tujuannya adalah untuk mencari kesamaan data dengan metode yang berbeda. Triangulasi dengan teori dilakukan dengan menguraikan pola, hubungan, dan menyertakan penjelasan yang muncul dari analisis untuk mencari tema atau penjelasan pembanding.

Penulis juga menggunakan triangulasi sumber metode dan teori untuk menguji keabsahan data dalam penelitian ini, karena penelitian yang penulis lakukan bersifat holistik yang memiliki hubungan yang kuat dengan pihak-pihak tertentu. Cara tersebut diharapkan penulis dapat memperoleh keabsahan dari data yang didapatkan dengan menyertakan pandangan atau pendapat pihak lain tentang permasalahan yang akan penulis teliti.

\section{HASIL DAN PEMBAHASAN}

Sebagai perusahaan BUMN yang terlibat dalam jasa bandar udara dan segala macam pelayanan yang berhubungan dengan bandar udara di Indonesia, PT Angkasa Pura II (Persero) 
harus dapat melaksanakan komitmennya untuk memberikan pelayanan yang terbaik salah satunya melalui aktivitas Customer Relationship Management (CRM). Setiap perusahaan memiki alasan tersendiri dalam melaksanakan aktivitas Customer Relationship Management (CRM), demikian pula halnya dengan PT Angkasa Pura II (Persero). Aktivitas customer relations dilakukan oleh PT Angkasa Pura II (Persero) dengan alasan sebagai berikut:

Alasan pertama adalah untuk mencapai misi, visi, tujuan dan sasaran PT Angkasa II (Persero). Misi, visi, tujuan dan sasaran merupakan hal utama yang harus dicapai oleh sebuah perusahaan termasuk oleh PT Angkasa Pura II (Persero). Untuk mencapai misi, visi, tujuan dan sasaran, Humas PT Angkasa II (Persero) memiliki peranan penting salah satunya melalui aktivitas Customer Relationship Management (CRM).

General Manager PT Angkasa Pura II (Persero) Bandara Internasional Husein Sastranegara Bandung, Dorma Manalu, menyampaikan pernyataan berikut:

"Yang pasti semua yang kita lakukan disini termasuk juga aktivitas Customer Relationship Management ya buat mencapai apa yang jadi visi, misi, tujuan sama sasaran Angkasa Pura. Itu kan kewajiban yang diberikan oleh pusat sama kita jadi ya harus kita capai.“ (Wawancara, 18 November 2015)

Alasan kedua adalah pentingnya mitra usaha bagi PT Angkasa Pura II (Persero). PT Angkasa Pura II (Persero) merupakan perusahaan pelayanan jasa bandar udara dimana dalam usahanya sangat memerlukan pelanggan dalam hal ini mitra usaha yang menyewa fasilitas yang disediakan. Melalui aktivitas Customer Relationship Management (CRM), PT Angkasa Pura II (Persero) berusaha untuk dapat menjalin hubungan baik dan kerja sama dengan berbagai pihak dalam hal ini pelanggan. Hal tersebut dikarenakan mitra usaha memiliki posisi yang sangat penting terutama dalam mendukung kemajuan dan berkembangnya Bandara Internasional Husein Sastranegara Bandung. Dengan terciptanya hubungan baik antara PT Angkasa Pura II (Persero) dengan mitra usaha diharapkan terjalin kerjasama yang lebih baik dan saling memberikan dukungan dalam mencapai tujuan perusahaan.
Alasan ketiga adalah menjaga komitmen antara PT Angkasa Pura II (Persero) dengan mitra usaha. PT Angkasa Pura II (Persero) selalu berusaha untuk menjaga komitmen dengan mitra usahanya salah satunya melalui pemberdayaan Humas untuk memberikan pelayanan yang terbaik melalui aktivitas Customer Relationship Management (CRM) demi membantu mitra usaha dalam mencapai tujuan perusahaan. Selain itu bentuk komitmen yang ditunjukan PT Angkasa Pura (Persero) lainnya adalah dengan membuat rencana kerja atau program-program yang menguntungkan bagi kedua belah pihak.

Alasan keempat adalah membina hubungan jangka panjang antara PT Angkasa Pura II (Persero) dengan mitra usaha. Hubungan yang dibina oleh Humas PT Angkasa Pura II (Persero) melalui aktivitas Customer Relationship Management (CRM) dari awal berdiri hingga saat ini lebih ditujukan kepada hubungan jangka panjang dengan pelanggannya sehingga kerjasama yang dijalin bisa terus berkelanjutan tidak hanya sesaat. Seperti disampaikan General Manager PT Angkasa Pura II (Persero) Bandara Internasional Husein Sastranegara Bandung, Dorma Manalu berikut ini:

"AP II merupakan perusahaan pelayanan jasa bandar udara ya kan. Nah dalam usaha itu kita ga mungkin dong kerja sendiri. Maka kita harus menjalin hubungan dan kerja sama dengan berbagai pihak dalam hal ini pelanggan. Ya salah satunya melalui itu ya melalui aktivitas customer relations. Pentingnya posisi pelanggan dalam hal ini mitra usaha bandara yaitu dalam mendukung kemajuan dan berkembangnya bandara ya, jadi kita ngga ada artinya kalo ga ada pelanggan kan. Jadi hubungan baik itu penting sekali" (Wawancara, 18 November 2015).

Alasan kelima adalah meningkatkan benefit bagi PT Angkasa Pura II (Persero) dan mitra usaha. Tidak dapat dipungkiri bahwa tujuan berdirinya PT Angkasa Pura II (Persero) adalah untuk mendapatkan benefit yang sebesar-besarnya terutama benefit dalam bentuk materi. Namun tidak mungkin PT Angkasa Pura II (Persero) dapat memperoleh benefit yang maksimal sesuai dengan misinya tanpa dukungan dari mitra usahanya sebagai pemberi benefit terbesar. Oleh karena itu dalam setiap aktivitasnya PT Angkasa Pura II (Persero) 
harus selalu berusaha untuk memberikan atau menciptakan mutual benefit termasuk dalam aktivitas Customer Relationship Management (CRM). Dengan melaksanakan aktivitas Customer Relationship Management (CRM), benefit yang diperoleh oleh PT Angkasa Pura II (Persero) dari mitra usaha tidak hanya berbentuk materi tetapi juga imateri seperti apresiasi atau penghargaan.

Alasan keenam adalah menjalin bentuk kerjasama kemitraan antara PT Angkasa Pura II (Persero) dengan mitra usaha. Dari awal berdiri hingga saat ini PT Angkasa Pura II (Persero) selalu berusaha menjalin hubungan kemitraan dengan pelanggannya sehingga kerjasama yang terbentuk lebih kepada mitra usaha bukan hanya sebagai provider dengan pelanggan. Dengan menyebut mitra usaha, PT Angkasa II (Persero) memiliki tujuan agar melalui kemitraan yang dilakukan bisa tercipta hubungan yang harmonis dan bersama-sama saling memberikan dukungan untuk mencapai tujuan perusahaan. Bentuk kemitraan tersebut ditunjukkan PT Angkasa Pura II (Persero) dengan saling menghargai fungsi dan tugasnya sekaligus menjalankan tanggung jawab masingmasing sehingga tidak ada pihak yang dirugikan.

Alasan ketujuh adalah meningkatkan kepercayaan mitra usaha dan calon mitra usaha kepada PT Angkasa Pura II (Persero) dimana kepercayaan dari mitra usaha merupakan faktor yang sangat penting. Dengan adanya kepercayaan dari mitra usaha kepada PTAngkasa Pura II (Persero) kerjasama yang terjalin bisa terus berlanjut bahkan bisa melahirkan bentukbentuk kerjasama baru. Melalui aktivitas Customer Relationship Management (CRM) yang dilaksanakannya, PT Angkasa Pura II (Persero) berharap kepercayaan mitra usahanya dapat lebih meningkat. Selain mitra usaha yang sudah ada, calon mitra usaha juga merupakan hal yang penting bagi PT Angkasa II (Persero). Dengan melakukan setiap aktivitas Customer Relationship Management (CRM) PT Angkasa Pura II (Persero) berharap dapat lebih diterima oleh mitra usahanya termasuk oleh calon mitra usahanya sehingga bisa mendatangkan lebih banyak mitra usaha ke Bandara Internasional Husein Sastra Negara Bandung.

Alasan kedelapan adalah mencari tahu kebutuhan dan kepentingan mitra usaha PT Angkasa Pura II (Persero). Mengetahui apa yang menjadi kebutuhan dan kepentingan mitra usaha merupakan hal yang selalu dilakukan oleh PT Angkasa Pura II (Persero) melalui aktivitas Customer Relationship Management (CRM), sehingga PT Angkasa Pura II (Persero) bisa menjalin kerjasama yang baik dengan mitra usahanya. Untuk mengetahui kepentingan dan kebutuhan mitra usaha tersebut PT Angkasa Pura II (Persero) melakukan interaksi secara langsung baik itu melalui pertemuan rutin ataupun pertemuan non rutin atau bisa juga dengan melalui kegiatan survei. Untuk dapat menciptakan good relationship, perusahaan harus mengetahui bahwa publik memiliki berbagai keinginan dan kebutuhan yang diharapkan perusahaan dapat memenuhinya dan memulai relationship terhadap kedua belah pihak, mendiskusikan berbagai masalah untuk kemudian dicari jalan keluarnya. Jika proses ini dapat berlangsung dengan baik, maka publik akan mengetahui bahwa keterlibatan mereka dalam suatu jalinan relationship dengan perusahaan yang bersangkutan ternyata memberikan keuntungan dan nilai tambah bagi diri mereka (Ledingham dan Bruning, 2000: 66). Hal inilah yang kemudian akan mendorong kepada terciptanya favorable relationship, yang mana menjadi salah satu faktor kunci keberhasilan perusahaan. Alasan terakhir PT Angkasa Pura II (Persero) melakukan strategi Customer Relationship Management (CRM) di Bandara Internasional Husein Sastranegara Bandung adalah menciptakan loyalitas pada mitra usaha PT Angkasa Pura II (Persero). Kegiatan membangun dan menjaga hubungan yang dijalin antara PT Angkasa Pura II (Persero) dengan mitra usaha melalui aktivitas Customer Relationship Management (CRM) merupakan usaha untuk membuat mitra usaha merasa nyaman dengan perusahaan dan pelayanan dari PT Angkasa Pura II (Persero) serta sebagai usaha untuk meningkatkan loyalitas mitra usaha sehingga dapat terbentuk kerjasama jangka panjang.

Tujuan yang ingin dicapai pada aktivitas Customer Relationship Management (CRM) yang dilakukan PT Angkasa Pura II (Persero) adalah lebih kepada upaya menciptakan hubungan baik jangka panjang dengan mitra usaha sehingga tercipta loyalitas pada mitra usaha. Untuk dapat mencapai tujuan tersebut PT Angkasa Pura II (Persero) melakukan beberapa aktivitas Customer Relationship Management (CRM) yang terdiri dari: 
Pertama, membuat rencana kerja jangka pendek dan jangka panjang PT Angkasa Pura II (Persero). Dalam melakukan setiap kinerjanya PT Angkasa Pura II (Persero) selalu membuat rencana kerja jangka pendek dan jangka panjang yang disebut dengan rancangan jangka panjang perusahaan (RJPP). Dengan membuat RJPP diharapkan semua kinerja PT Angkasa Pura (Persero) termasuk kinerja Humas dalam melakukan aktivitas Customer Relationship Management (CRM) dapat berjalan dengan efektif demi tercapainya tujuan perusahaan serta mitra usaha. Kinerja PT Angkasa Pura II (Persero) sangat dipengaruhi oleh PT Angkasa Pura Pusat, oleh karena itu koordinasi yang baik harus dilakukan oleh PT Angkasa Pura II (Persero) cabang Bandung agar bisa melakukan kinerjanya secara maksimal dan memberikan kepuasan kepada mitra usaha. Koordinasi tersebut dilakukan tergantung dari tugas atau pekerjaan itu sendiri, apabila berkaitan dengan hal-hal yang prinsip dan memerlukan kebijakan yang sifatnya korporasi maka dilakukan koordinasi dengan pusat dan apabila tidak, dapat dikelola atau dikerjakan lansgung oleh PT Angkasa Pura II (Persero) cabang Bandung.

Kedua, melakukan kegiatan survei kepuasan konsumen kepada mitra usaha, mitra kerja dan penumpang. Untuk mengetahui segala sesuatu yang berhubungan dengan mitra usaha, mitra kerja dan penumpang di Bandara Internasional Husein Sastranegara, PT Angkasa Pura II (Persero) selalu melakukan survei setiap tahunnya. Survei tersebut dilakukan dengan menggunakan SLA (Service Level Agreement) dan SLG (Service Level Guarantee) dengan survei Customer Satisfaction Index (CSI) yang dilakukan setiap tahun sekali oleh penilaipenilai independen. Menurut Cutlip, (2007: 62) tahap yang dilakukan PT Angkasa Pura II (Persero) ini merupakan tahap sebagai suatu usaha atau kegiatan untuk menentukan nilai suatu program atau kegiatan. Oleh karena itu, untuk mengetahui mana kebutuhan, keinginan dan harapan pelanggan terpenuhi perlu diukur dengan berbagai metode (kepuasan pelanggan).

Ketiga, selalu menjaga keterbukaan informasi kepada mitra usaha, mitra kerja dan masyarakat. Keterbukaan merupakan faktor penting bagi masyarakat ataupun mitra usaha dan mitra kerja. Oleh karena itu PT Angkasa Pura II (Persero) selalu berusaha untuk menghindari masalah keterbukaan dengan menyampaikan semua informasi yang layak untuk diketahui oleh masyarakat atau mitra usaha dan mitra kerjanya. Keterbukaan yang dilakukan oleh PT Angkasa Pura II (Persero) merupakan salah satu bentuk kepatuhannya pada undangundang keterbukaan informasi publik. Dalam menjaga keterbukaan informasi PT Angkasa Pura II (Persero) melakukannya dengan cara menyediakan kemudahan akses informasi dan komunikasi bagi mitra usaha dan mitra kerja. Untuk mempermudah kegiatan komunikasi serta penyebaran informasi PT Angkasa Pura II (Persero) menyediakan website dan media sosial salah satunya adalah twitter. Selain itu PT Angkasa Pura II (Persero) juga tanggap dalam memberikan respons terhadap pertanyaaan atau permasalahan yang disampaikan di media daring atau media lainnya termasuk media massa baik cetak ataupun elektronik. Dengan menggunakan strategi tersebut pihak PT Angkasa Pura II (Persero) berharap dapat tercipta komunikasi dua arah antara pelanggan dengan PT Angkasa Pura II (Persero) sehingga komunikasi yang dilakukan dapat berjalan dengan efektif.

Keempat, melakukan pertemuan rutin dan tidak rutin dengan mitra usaha dan mitra kerja. Untuk mengetahui apa yang menjadi keinginan mitra usaha dan mitra kerja, PT Angkasa Pura II (Persero) sering melakukan pertemuan dengan mitra usaha dan mitra kerjanya melalui program fasilitation yang merupakan program pertemuan rutin dan tidak rutin yang dilakukan PT Angkasa Pura (Persero) dengan mitra usaha dan mitra kerjanya baik secara formal ataupun informal. Selain melakukan kegiatan untuk membina hubungan baik dengan pelanggan yang sudah ada melalui program fasilitation, PT Angkasa Pura II Persero juga selalu mengikuti kegiatan-kegiatan atau pertemuanpertemuan yang bisa mendatangkan pelanggan baru seperti pertemuan Humas ataupun pertemuan pertemuan yang ada di Kementerian Perhubungan.

Kelima, melakukan pelayanan program inovasi. Untuk dapat bersaing dengan bandarabandara lainnya di Indonesia, PT Angkasa Pura II (Persero) cabang Bandung selalu membuat program inovasi. Program inovasi dibuat untuk menciptakan image positif PT Angkasa Pura II (Persero) serta untuk membedakan kinerja PT Angkasa Pura II (Persero) cabang Bandung dengan cabang-cabang lainnya.

Keenam adalah bersikap adil kepada 
seluruh mitra usaha, dimana dalam memberikan pelayanan PT Angkasa Pura II (Persero) selalu berusaha bersikap adil baik itu kepada mitra usaha BUMS ataupun BUMN. Bagi PT Angkasa Pura II (Persero) tidak ada perlakuan khusus bagi mitra usaha yang ada. Semua maskapai itu sama, merupakan mitra usaha dan dengan melakukan hal tersebut PT Angkasa Pura II (Persero) berharap adanya sikap positif dari mitra usaha.

Ketujuh adalah dengan melakukan kegiatan monitoring terhadap mitra usaha. PT Angkasa Pura II (Persero) selalu melakukan kegiatan monitoring terhadap segala sesuatu yang terjadi di Bandara Internasional Husein Sastranegara. Kegiatan monitoring dilakukan untuk mengetahui hal-hal yang berhubungan dengan mitra usaha ataupun pemberitaan tentang PT Angkasa Pura II (Persero) atau Bandara Internasional Husein Sastranegara di media massa.

Kedelapan adalah melakukan skala perioritas dalam menanggapi permintaan dan keluhan mitra usaha. Setiap permintaan dan keluhan yang masuk ke PT Angkasa Pura II (Persero) pasti akan ditanggapi, namun dalam memberikan tanggapan tersebut ada skala prioritas yang dilakukan terutama dengan melihat bobot dari permintaan atau keluhan tersebut. Apabila bisa dipenuhi dalam waktu cepat maka PT Angkasa Pura II (Persero) akan berusaha dengan cepat untuk menanggapinya namun apabila permintaan atau keluhan tersebut memerlukan biaya yang besar atau koordinasi dengan pusat, maka PT Angkasa Pura II (Persero) akan melakukan hal-hal yang diperlukan untuk memenuhi permintaan atau keluhan tersebut dengan tetap berusaha menjaga kualitas dari pelayanannya.

Kesembilan adalah dengan memenuhi dan menepati janji kepada mitra usaha. Untuk dapat terus membina hubungan baik dengan pelanggan salah satu cara yang harus dapat dilakukan pihak PT Angkasa Pura II (Persero) adalah dengan memenuhi dan menepati setiap janjinya kepada mitra usaha termasuk dalam membuat program-program kerjanya yang harus memperhatikan kepentingan mitra usaha.

Kesepuluh yaitu selalu melakukan tindakan preventif. Dalam memberikan kepuasan kepada pelanggan dengan tujuan untuk meningkatkan loyalitas pelanggan, PT Angkasa Pura II Persero selalu berusaha untuk melakukan tindakan preventif dalam segala hal, terutama dalam hal untuk mencegah munculnya keluhan dari mitra usaha. Selain tindakan preventif, PT Angkasa Pura II (Persero) juga selalu berusaha untuk memberikan bantuan kepada mitra usaha apabila terjadi permasalahanyang menimpanya. Dengan melakukan tindakan prefentif sebenarnya PT Angkasa Pura II (Persero) menggunakan strategi yang merupakan alat untuk mencapai tujuan. Tujuan utamanya adalah agar perusahaan dapat melihat secara objektif kondisi-kondisi internal dan eksternal, sehingga perusahaan dapat mengantisipasi perubahan lingkungan eksternal (Rangkuti, 2009: 3).

Terakhir adalah melakukan evaluasi dan meningkatkan pembinaan hubungan dengan mitra usaha. Salah satu langkah yang sangat penting dalam melakukan aktivitas Customer Relationship Management (CRM) adalah dengan selalu melakukan evaluasi dimana dengan evaluasi PT Angkasa Pura II (Persero) dapat mengetahui segala kelebihan serta kekurangan dari kinerjanya agar dapat dengan cepat melakukan perbaikan untuk lebih meningkatkan hubungan baik diantara PT Angkasa Pura II (Persero) dengan mitra usahanya. Tabel 2 berisi pengelompokan dari pemaparan di atas, mengenai alasan serta strategi Customer Relationship Management (CRM) PT Angkasa Pura II (Persero) di Bandara Internasional Husein Sastranegara Bandung.

Persepsi pelanggan pada strategi Customer Relationship Management (CRM) yang dilakukan PT Angkasa Pura II (Persero) di Bandara Internasional Husein Sastranegara Bandung adalah persepsi dari mitra usaha, mitra kerja serta penumpang yang menggunakan Bandara Internasional Husein Sastranegara Bandung. Persepsi yang disampaikan mitra usaha, mitra kerja dan penumpang bermacammacam, ada persepsi yang berupa pujian diantaranya PT Angkasa Pura II (Persero) selalu menjaga hubungan baik, melayani mitra usaha, mitra kerja dan penumpang dengan baik, berlaku adil kepada mitra usaha, aktif dalam memberikan informasi kepada mitra usaha, mitra kerja dan penumpang, melibatkan mitra usaha, mitra kerja dan penumpang dalam membuat setiap kebijakan baru, merasa cukup puas dengan kinerja PT Angkasa Pura II (Persero), terciptanya mutual benefit dan cukup dapat diandalkan oleh mitra usaha dan mitra kerja. Persepsi pelanggan di atas dapat dikatakan 
Tabel 2 Persepsi pelanggan pada strategi Customer Relationship Management (CRM) yang dilakukan PT Angkasa Pura II (Persero) di Bandara Internasional Husein Sastranegara Bandung

\author{
Alasan PT Angkasa Pura II (Persero) \\ melakukan strategi Customer Relationship \\ Management (CRM)di Bandara \\ Internasional Husein Sastranegara \\ Bandung.
}

\section{Strategi Customer Relationship Management (CRM) PT Angkasa Pura II (Persero) di Bandara Internasional Husein Sastranegara Bandung.}

Membuat rencana kerja jangka pendek dan jangka panjang

Melakukan kegiatan survei kepuasan konsumen kepada mitra usaha, mitra kerja dan penumpang.

Menjaga keterbukaan informasi kepada mitra usaha, mitra kerja dan masyarakat.

Melakukan pertemuan rutin dan tidak rutin dengan mitra usaha dan mitra kerja

Melakukan pelayanan program inovasi

Menjaga komitmen antara PT
(Persero) dengan mitra usaha

Membina hubungan jangka panjang antara PT Angkasa Pura II (Persero) dengan mitra usaha

Meningkatkan benefit bagi PT Angkasa Pura II (Persero) dan mitra usaha

Menjalin bentuk kerjasama kemitraan antara PT Angkasa Pura II (Persero) dengan mitra usaha

Meningkatkan kepercayaan mitra usaha dan calon mitra usaha kepada PT Angkasa Pura II (Persero).

Mencari tahu kebutuhan dan kepentingan mitra usaha PT Angkasa Pura II (Persero).

Menciptakan loyalitas pada mitra usaha PT Angkasa Pura II (Persero).
Bersikap adil kepada seluruh mitra usaha

Melakukan kegiatan monitoring terhadap mitra usaha

Melakukan skala prioritas dalam menanggapi permintaan dan keluhan mitra usaha.

Memenuhi dan menepati janji kepada mitra usaha

Melakukan tindakan preventif

Melakukan evaluasi dan meningkatkan pembinaan hubungan dengan mitra usaha

Sumber: Penelitian, 2016

merupakan penghargaan bagi PT Angkasa Pura II (Persero) dalam melakukan setiap kinerjanya termasuk dalam melakukan aktivitas Customer Relationship Management (CRM). Keberhasilan dari pelaksanaan relationship antara organisasi dengan publiknya ini tergantung pada kemauan masing-masing pihak untuk menyelaraskan berbagai kepentingannya serta kerjasama dari kedua belah pihak tersebut dalam upaya mencari solusi bagi masalah yang dialami oleh pihak lainnya.
Sedangkan persepsi yang berupa keluhan terhadap kinerja PT Angkasa Putra II (Persero) diantaranya adalah hubungan yang terjalin bukan sebagai mitra usaha, mitra usaha membayarnya jasa pelayanan persection, masih ada kekurangan dalam penyediaan jasa, masih belum bisa menepati janji kepada mitra usaha, kurang menyosialisasikan programprogram inovasi kepada mitra usaha, harus lebih intensif dalam memberikan informasi kepada pelanggannya. Keluhan pelanggan 
menurut Rusady (2004: 56) merupakan ungkapan dari ketidakpuasan yang dirasakan oleh konsumen. Keluhan pelanggan adalah hal yang tidak dapat diabaikan karena dengan mengabaikan hal tersebut akan membuat konsumen merasa tidak diperhatikan dan pada akhirnya perusahaan akan ditinggalkan oleh konsumen. Berdasarkan pendapat di atas, PT Angkasa Pura II (Persero) harus secepatnya melakukan perbaikan-perbaikan terutama dalam hal pelayanan yang diberikan kepada mitra usaha, mitra kerja dan penumpang. Adanya persepsi positif atau negatif dari mitra usaha, mitra kerja dan penumpang pada strategi Customer Relationship Management (CRM) yang dilakukan PT Angkasa Pura II (Persero) dapat dipengaruhi beberapa faktor diantaranya status pendidikan, usia, jenis kelamin, profesi mitra usaha, mitra kerja dan penumpang.

\section{SIMPULAN}

Aktivitas Customer Relationship Management (CRM) dilakukan oleh PT Angkasa Pura II (Persero) dengan berbagai macam alasan, yang paling utama adalah untuk mencapai misi, visi, tujuan dan sasaran PT Angkasa II (Persero). Alasan lainnya adalah karena pentingnya mitra usaha bagi PT Angkasa Pura II (Persero) dimana demi keberlangsungan usahanya sangat memerlukan mitra usaha. Oleh karena itu PT Angkasa Pura II (Persero) perlu menjaga komitmen, menciptakan mutual benefit, serta mengetahui apa yang menjadi kebutuhan mitra usaha serta menciptakan kepercayaan dari mitra usaha agar dapat meningkatkan loyalitas mitra usaha kepada PT Angkasa Pura II (Persero).

\section{Strategi Customer Relationship} Management (CRM) yang dilakukan PT Angkasa Pura II (Persero) di Bandara Internasional Husein Sastranegara Bandung merupakan salah satu aktivitas pelayanan yang dilakukan PT Angkasa Pura II (Persero) kepada mitra usahanya. Aktivitas tersebut dilakukan PT Angkasa Pura II (Persero) melalui membuat rencana kerja jangka panjang dan jangka pendek termasuk didalamnya melakukan aktivitas survei kepuasan kosumen, menjaga keterbukaan informasi kepada mitra usaha, mitra kerja dan masyarakat, melakukan pertemuan-pertemuan baik secara rutin ataupun tidak rutin untuk mengetahui apa yang menjadi keinginan mitra usaha dan mitra kerja, melakukan pelayanan program inovasi serta selalu bersikap adil dalam menanggapi permintaan atau keluhan mitra usaha yang diakhiri dengan melakukan evaluasi pada seluruh kinerjanya sehingga PT Angkasa Pura II (Persero) dapat mengetahui segala kekurangan dari kinerjanya dan dapat secepatnya melakukan perbaikan untuk lebih meningkatkan hubungan baik diantara PT Angkasa Pura II (Persero) dengan mitra usahanya.

Persepsi pelanggan pada strategi Customer Relationship Management (CRM) yang dilakukan PT Angkasa Pura II (Persero) di Bandara Internasional Husein Sastranegara Bandung adalah persepsi dari mitra usaha, mitra kerja serta penumpang yang menggunakan Bandara Internasional Husein Sastranegara Bandung. Persepsi yang disampaikan mitra usaha, mitra kerja dan penumpang yang merupakan hasil interaksi antara mereka dengan PT Angkasa Pura II (Persero) ada yang berupa pujian dan keluhan. Pujian serta keluhan yang diberikan oleh mitra usaha, mitra kerja serta penumpang merupakan apresiasi atas perasaan puas dan tidak puas dari mereka terhadap kualitas pelayanan yang dilakukan oleh PT Angkasa Pura II (Persero). Perasaan puas dan tidak puas dari mitra usaha, mitra kerja serta penumpang harus benar-benar disikapi oleh PT Angkasa Pura II (Persero) agar dapat menciptakan favorable relationship dengan cara memberikan pelayanan yang berkualitas kepada mitra usaha, mitra kerja serta penumpang dan juga mengembangkan hubungan yang berlandaskan rasa saling percaya dan menghargai kepentingan pihak lain.

Beberapa saran yang dapat diusulkan dari penelitian ini adalah: (1) PT Angkasa Pura II (Persero) sebaiknya membuat divisi khusus Humas tersendiri sebagai pelaksana kegiatan kehumasan agar pekerjaan tidak menumpuk di salah satu divisi untuk dapat menciptakan kinerja yang lebih baik, (2) PT Angkasa Pura II (Persero) sebaiknya lebih banyak melakukan sosialisasi tentang program-program inovasi yang dibuatnya agar bisa bermanfaat juga bagi mitra usaha, (3) PT Angkasa Pura II (Persero) sebaiknya lebih kreatif dan inovatif dalam melakukan strategi Customer Relationship Management (CRM) terutama aktivitas Customer Relationship Management (CRM) yang ditujukan untuk penumpang maskapai. 


\section{DAFTAR PUSTAKA}

Barnes, J. G. (2003). Secrets of customer relationship management. Yogyakarta: Andi.

Cutlip, S. M., Center, A. H. \& Broom, G. M. (2006). Effective public relations: edisi kesembilan. Jakarta: Kencana Prenada Media Grup.

Cresswell, J. W. (2012). Qualitative inquiry and research design: choosing among five traditions. Landon: Sage Publications. . (2012). Research design: pendekatan kualitatif, kuantitatif, dan mixed. Terjemahan achmad fawaid. Yogyakarta: Pustaka Pelajar.

Datuela, A. (2013). Strategi public relations pt. telkomsel branch manado. Ac, i(i), 3-15.

Effendy, O. U. (2007). Ilmu, teori dan filsafat komunikasi. Bandung: Citra Aditya Bakti.

Ishak. (2006). Pengelolaan perpustakaan berbasis teknologi informasi. Jurnal Studi Perpustakaan Dan Informasi, 2, 93.

Kasali, R. (2014). Agility, bukan singa yang mengembik. Jakarta: Gramedia Pustaka Utama.

Kriyantono, R. (2008). Teknik praktis: riset komunikasi. Jakarta: Kencana Prenada Media Group.

Ledingham, J. A., Bruning, S. D., \& Wilson, L. J. (2000). Time as an indicator of the perceptions and behavior of members of a key public: monitoring and predicting organization-public relationships. Journal Of Public Relations Research.

Mukhroman, I. (2013). Perencanaan strategi humas pemprov banten pasca ditetapkannya kek pariwisata tanjung lesung pandeglang banten. Jurnal Kajian Komunikasi, Volume 1, No. 2, Desember 2013 hlm 206-208.
Diakses dari http: //journal.unpad.ac.id/ jkk/article/view/6045/3156, tanggal 01 Juni 2016.

Moleong, L. J. (2005). Metodologi penelitian kualitatif. Bandung: Remaja Rosdakarya.

PT Angkasa Pura II. (2016). Arsip pt angkasa pura ii.

Rangkuti, F. (2009). Strategi promosi yang kreatif dan analisis kasus integrated marketing communication. Jakarta: PT. Gramedia Pustaka Utama.

Ruslan, R. (2004). Manajemen humas \& manajemen komunikasi: konsep dan aplikasi. Jakarta: Rajawali Pers.

Semuel, H. (2012). Customer relationship marketing pengaruhnya terhadap kepercayaan dan loyalitas perbankan nasional. Jurnal Manajemen Pemasaran, 7(1), 33-41. https://doi.org/10.9744/ pemasaran.7.5.33-41.

Sugiyono. (2012). Metode penelitian kuantitatif dan kualitatif. Bandung: Alfabeta.

Turban, E., King, L., \& Chung. (2002). Electronic commerce 2002: a managerial perspective. Pearson education inc. New Jersey: Upper Saddle River.

Utami, C. W. (2006). Relationship effort dan kualitas layanan sebagai strategi penguat relationship outcomes (sebuah tinjauan konseptual dalam bisnis ritel modern di indonesia). Jurnal Manajemen Pemasaran, 1(1), 22-34. https://doi.org/10.9744/ pemasaran.1.1.

Yin, R. K. (2006). Studi kasus: desain dan metode. Jakarta: Raja Grafindo Persada.

$\mathrm{Ken} / \mathrm{ndr}$.(2011). 3 kondisibandarainternasional di indonesia mencemaskan. Diakses dari http://news.detik.com/berita/1658147/ cidev-3-kondisi-bandara-internasional-diindonesia-mencemaskan/, pada tanggal 10 Januari 2016. 